\title{
A new species of planthopper in genus Herpis (Hemiptera: Derbidae) from lowland tropical rainforest in Costa Rica
}

\author{
BRIAN W. BAHDER ${ }^{1}$, MARCO A. ZUMBADO ECHAVARRIA², EDWIN A. BARRANTES BARRANTES ${ }^{3}$, \\ ERICKA E. HELMICK ${ }^{4} \&$ CHARLES R. BARTLETT ${ }^{5}$ \\ ${ }^{1}$ University of Florida, Department of Entomology and Nematology - Fort Lauderdale Research and Education Center; 3205 College \\ Ave., Davie, FL 33314-7719, USA. \\ "=bbahder@ufl.edu; ○ https://orcid.org/0000-0002-1118-4832 \\ ${ }_{2}^{2}$ Universidad de Costa Rica - Sede San Ramón, Departamento de Ciencias Naturales, de la Iglesia el Tremedal 400 mts al Oeste car- \\ retera hacia San Pedro, San Ramón, Alajuela, Costa Rica. \\ इ"nassua75@gmail.com; — https://orcid.org/0000-0002-2591-7662 \\ ${ }^{3}$ Universidad de Costa Rica - Sede San Ramón, Departamento de Ciencias Naturales, de la Iglesia el Tremedal 400 mts al Oeste car- \\ retera hacia San Pedro, San Ramón, Alajuela, Costa Rica. \\ ="edwbarrantes@gmail.com; @ https://orcid.org/0000-0001-9565-2105 \\ ${ }^{4}$ University of Florida, Department of Entomology and Nematology - Fort Lauderdale Research and Education Center; 3205 College \\ Ave., Davie, FL 33314-7719, USA. \\ "="ehelmick@ufl.edu; @ https://orcid.org/0000-0002-5153-0891 \\ ${ }^{5}$ University of Delaware, Department of Entomology and Wildife Ecology, 250 Townsend Hall, Newark, DE 19716-2160, USA.

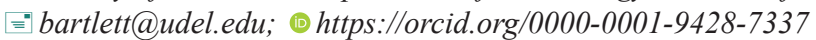 \\ Corresponding Author.
}

\begin{abstract}
Recent survey efforts in the Neotropics have documented a variety of new species of planthoppers associated with palms. Herein, a new species, Herpis soros sp. n., is described from palms in lowland tropical rainforest from Costa Rica. Other species in the genus ( $H$. metcalfi, H. albida, and H. fuscovittata) are evaluated to provide an updated diagnosis of the genus Herpis. The New World Phaciocephalus is examined because two species were described in the genus Herpis with P. fimbriolata being recorded for both Herpis and Phaciocephalus. After examining holotype material for the New World Phaciocephalus, two species were determined to belong to other genera resulting in new combinations Oropuna orba comb. n. and Persis (Anapersis) pallidovenosa comb. n. The synonymy of Syntames with Herpis is reviewed, with $S$. fuscus moved to Oropuna as Oropuna fusca comb. n. Finally, molecular analysis of the new species based on COI and $18 \mathrm{~S}$ show strong support for $H$. soros sp. n. as a distinct clade relative to all other cenchreines available.
\end{abstract}

Key words: palms, biodiversity, DNA barcoding, survey, taxonomy, phylogenetics

\section{Resumen}

Los recientes muestreos en el Neotrópico han documentado una variedad de nuevas especies de chicharritas asociadas a las palmeras. En esta investigación, se describe una nueva especie denominada Herpis soros sp. n. Esta chicharrita se encontró asociada a palmeras en el bosque lluvioso tropical de tierras bajas de Costa Rica. En este documento, se evalúan también otras especies del género (H. metcalfi, H. albida y H. fuscovittata) con el fin de proporcionar un diagnóstico actualizado del género Herpis. Se examina Phaciocephalus del Nuevo Mundo porque dos especies fueron descritas en el género Herpis, con P. fimbriolata descrita para ambos géneros: Herpis y Phaciocephalus. Después de examinar el holotipo para Phaciocephalus del Nuevo Mundo, se determinó que dos de las especies pertenecen a otro género; resultando en estas nuevas combinaciones propuestas Oropuna orba comb. n. y Persis (Anapersis) pallidovenosa comb. n. Además, se revisó la sinonimia de Syntames con Herpis. La especie S. fuscus es trasladada a Oropuna como Oropuna fusca comb. n. Finalmente, el análisis molecular de la nueva especie basado en COI y 18S; confirma que $H$. soros sp. n. pertenece a un clado distinto en relación a todas las demás especies de Cenchreini disponibles.

Palabras clave. palmeras, biodiversidad, códigos de barras de ADN, encuesta, taxonomía, filogenia. 


\section{Introduction}

The genus Herpis Stål (type species Herpis fuscovittata Stål from Brazil; Muir 1924, McAtee 1924, Metcalf 1945a) is a moderate sized group of derbid planthoppers in the tribe Cenchreini of the subfamily Derbinae. The Cenchreini are 'cixiid-like' derbids, with tectiform wings and the pronotal paradiscal regions forming foliate, cup-like fossae that partly circumscribes the antennae. Among New World cenchreine genera, Herpis is recognized as being moderately robust, approximately 4-8 $\mathrm{mm}$ (with wings), with broad frons (not concave) bearing parallel lateral margins and a well-defined median carina. The most similar genera of New World Cenchreini appear to be Oropuna Fennah and perhaps Omolicna Fennah, but neither of these genera have a median carina on the frons.

As currently defined, Herpis includes 15 species (Bourgoin 2021), including 10 Neotropical and five Indomalayan (viz. Philippines, India and Borneo; Muir 1917, Metcalf 1945a, Bourgoin 2021). The genus-level placement of these Indomalayan taxa deserves review, but that is not the intended task of the current project.

The genus Syntames Fowler (type species S. delicatus Fowler from Guatemala and Panama; Fowler 1905) has been variously treated as a junior synonym of Herpis (e.g., Muir 1924, Caldwell 1944, O’Brien 1982, 1987) or as a separate genus (e.g., Metcalf 1938, 1945a,b), leaving some residual uncertainty regarding the relative status of the two genera.

Recent surveys in the Caribbean focusing on planthoppers associated with palms has yielded a new species belonging to Herpis. Herein a novel species of Herpis collected from palms in lowland tropical rainforest in Costa Rica is described, COI and $18 \mathrm{~S}$ sequence data for the novel taxon is presented, and an updated phylogeny of the Cenchreini based on available sequence data is generated. The genus-level diagnostic features based on morphology of other available species in, or potentially in, Herpis is reviewed.

\section{Materials and Methods}

Locality and Specimen Collection. Individuals of the novel taxon were collected by sweep netting trailside palms, aspirated and were immediately transferred to $95 \%$ ethanol. Specimens were collected (permit no. SINAC-ACToGASPPNI-016-2018) at La Selva Biological Station, Heredia province, Costa Rica (10.431269, -84.005961), and exported under permit number DGVS-256-2018 to the U.S.A. under permit number P526-170201-001. All specimens collected were measured, photographed and dissected using a Leica M205 C stereoscope. Images of specimens and all features photographed were generated using the LAS Core Software v4.12. Voucher specimens, including primary types, are stored at the University of Florida - Fort Lauderdale Research and Education Center (FLREC) in Davie, FL, U.S.A and the Florida State Collection of Arthropods (FSCA) in Gainesville, FL, U.S.A. Label data were recorded for type specimens with label data quoted verbatim using "/" to indicate a line break and "//" to indicate a new label and with supplemental information given in brackets. For non-type specimens, label data were rewritten to maintain consistency in pattern, beginning with country, state or province, followed by more specific locality data, collection date, collector and lastly the number, sex and specimen depository given in parentheses.

Morphological terminology and identification. Morphological terminology generally follows that of Bartlett et al. (2014), except forewing venation following Bourgoin et al. (2015) and with male terminalia nomenclature modified after Bourgoin (1988) and Bourgoin \& Huang (1990).

Dissections and DNA Extraction. The terminalia that were dissected also served as the source of tissue for DNA extraction. The terminal end of the abdomens was removed and placed directly into a solution of tissue lysis buffer (buffer ATL) and proteinase K (180 $\mu \mathrm{ATL}$ and $20 \mu \mathrm{l}$ proteinase K) from the DNeasy ${ }^{\circledR}$ Blood and Tissue Kit (Qiagen). The abdomen was left to lyse for 24 hours at $56^{\circ} \mathrm{C}$. Following lysis, eluate was transferred to a new 1.5 $\mathrm{ml}$ microcentrifuge tube and DNA extraction proceeded as per the manufacturer's instructions. The terminalia were then immersed in $200 \mu \mathrm{l}$ of buffer ATL and $200 \mu \mathrm{l}$ of buffer AL from the same kit and placed at $95^{\circ} \mathrm{C}$ for 24 hours to remove fat, wax, and residual tissue.

PCR Parameters, Sequence Data, and Analysis. To obtain COI sequence data, DNA template from specimens was amplified using the primers TY-J-1460 (5'- TACAATTTATCGCCTAAACTTCAGCC -3') (Simon et al. 1994) and HCO2198 (5'-TCAGGGTGACCAAAAAAATCA-3') (Folmer et al. 1994). To obtain 18S sequence data, the forward primer 18S Fulfwd1 (5'- GGATAACTGTGGTAATTCTAG -3') (Urban \& Cryan 2007) and reverse primer 18SR (5'-GTCCGAAGACCTCACTAAA-3') (Bahder et al. 2019) were used. PCR reactions contained 5x GoTaq 
Flexi Buffer, $25 \mathrm{mM} \mathrm{MgCl} 2,10 \mathrm{mM}$ dNTP's, $10 \mathrm{mM}$ of each primer, 10\% PVP-40, and 2.5U GoTaq Flexi DNA Polymerase, $2 \mu \mathrm{DNA}$ template, and sterile $\mathrm{dH}_{2} 0$ to a final volume of $25 \mu \mathrm{L}$. Thermal cycling conditions for COI were as follows: $2 \mathrm{~min}$ initial denaturation at $95^{\circ} \mathrm{C}$, followed by 35 cycles of $30 \mathrm{sec}$ denaturation at $95^{\circ} \mathrm{C}, 30 \mathrm{sec}$ annealing at $40^{\circ} \mathrm{C}, 1 \mathrm{~min} 30 \mathrm{sec}$ extension at $72^{\circ} \mathrm{C}$, followed by a $5 \mathrm{~min}$ extension at $72^{\circ} \mathrm{C}$. Thermal cycling conditions for $18 \mathrm{~S}$ were as follows: $2 \mathrm{~min}$ initial denaturation at $95^{\circ} \mathrm{C}$, followed by 35 cycles of $30 \mathrm{sec}$ denaturation at $95^{\circ} \mathrm{C}$, $30 \mathrm{sec}$ annealing at $55^{\circ} \mathrm{C}, 2 \mathrm{~min}$ extension at $72^{\circ} \mathrm{C}$, followed by a 5 min extension at $72^{\circ} \mathrm{C}$. PCR products of the appropriate size were purified using the Exo-SAP-IT ${ }^{\mathrm{TM}}$ PCR Product Cleanup Reagent (ThermoFisher Scientific, Waltham, Massachusetts, USA). Purified PCR product was quantified using a NanoDropLite spectrophotometer (ThermoFisher Scientific, Waltham, Massachusetts, USA) and sent for sequencing at Eurofins Scientific (Louisville, KY, USA). Contiguous files were assembled using DNA Baser (Version 4.36) (Heracle BioSoft SRL, Pitesti, Romania), aligned using ClustalW as part of the package MEGA7 (Kumar et al. 2016). A matrix of pairwise differences using number of differences among COI and $18 \mathrm{~S}$ was calculated with MEGA7 (Kumar et al. 2016). The bootstrap method was used for variance estimation at 1,000 replicates and using the p-distance model. A Maximum Likelihood tree was generated using the Bootstrap method at 1,000 replicates based on the Tamura-Nei model for concatenated COI and $18 \mathrm{~S}$ data to yield a consensus tree.

Taxon sampling. For both the COI and 18S loci, DNA sequence data was used from eight species of Omolicna, four species of Agoo Bahder \& Bartlett, two species of Tico Bahder \& Bartlett (Bahder et al. 2021), Anchimothon dubia (Caldwell), Cenchrea dorsalis Westwood, and Neocenchrea heidemanni (Ball) to generate a consensus tree (Table 1). Additionally, specimens of H. metcalfi O'Brien (Fig. 1) and H. albida (Metcalf) (Fig. 2) were examined. Photographs of type material for H. fuscovittata Stål (Fig. 3), H. orba Stål (Fig. 4), H. fimbriolata Stål (Fig. 5) and H. pallidovenosa Stål (Fig. 6) (from the Swedish Royal Museum of Natural History Sweden, Stockholm, NHRS), Syntames fusca Metcalf (Fig. 7) (from the Museum of Comparative Zoology, Harvard, MCZC), were also examined, along with the type specimen of Phaciocephalus vitiensis Kirkaldy (from the Bernice P. Bishop Museum, Honolulu, HA, BPBM) for generic comparison.

TABLE 1. Taxa used for constructing phylogeny based on the COI and $18 \mathrm{~S}$ genes and performing pairwise comparisons.

\begin{tabular}{lll}
\hline Species & GenBank Accession No. & \\
\hline & COI & $18 \mathrm{~S}$ \\
Agoo beani & MT413388 & MT415403 \\
Agoo dahliana & MN496467 & MH472754 \\
Agoo luzdenia & MT085818 & MN999709 \\
Agoo xavieri & MK443068 & MK443073 \\
Anchimothon dubia & MN496470 & MN474755 \\
Anotia firebugia & MT084365 & MT945942 \\
Cenchrea dorsalis & MT413387 & MN472756 \\
Neocenchrea heidemanni & MN496473 & MT415406 \\
Omolicna brunnea & MK443070 & MK443071 \\
Omolicna cubana & MT413386 & MT415404 \\
Omolicna joi & KF472312 & MN472753 \\
Omolicna latens & MN496472 & MN472757 \\
Omolicna mariajoseae & MT422534 & MT424915 \\
Omolicna puertana & MN496468 & MN472751 \\
Omolicna tarco & MT422533 & MT424914 \\
Omolicna triata & MK443069 & MK443072 \\
Tico emmettcarri & MT085816 & MT526036 \\
Tico pseudosoroius & MT997938 & MT526037 \\
Herpis soros sp. n. & MT085817 & MT415406 \\
\hline
\end{tabular}




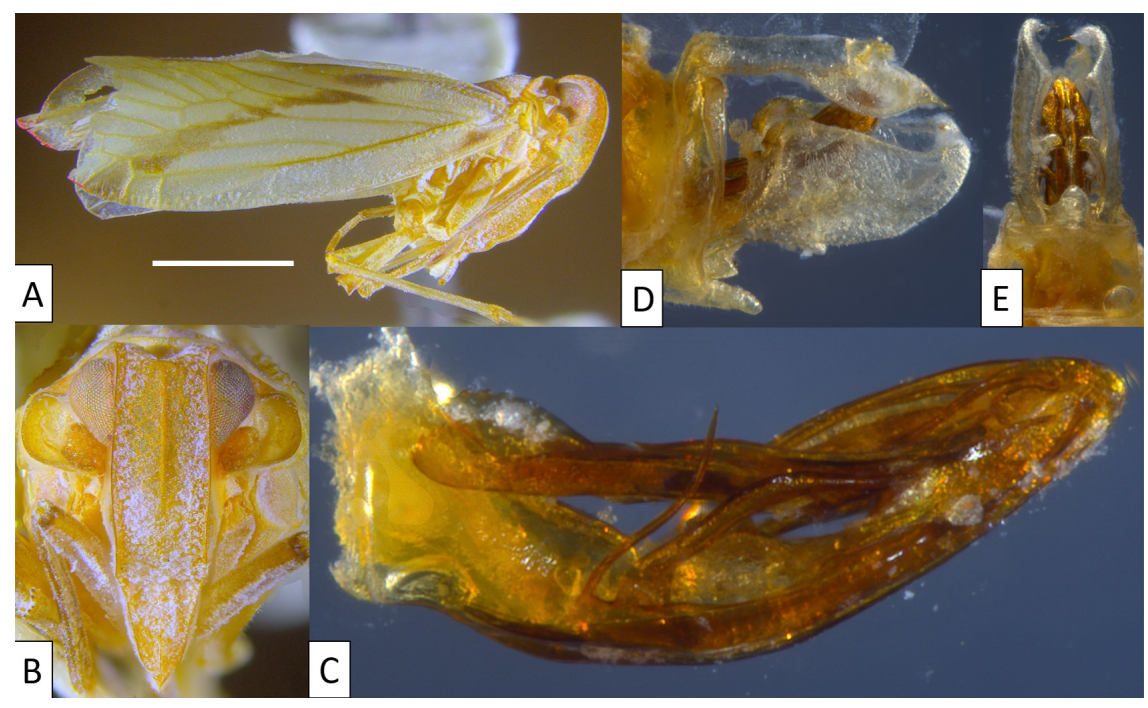

FIGURE 1. Herpis metcalfi; (A) adult male, lateral view, (B) head, frontal view, (C) aedeagus, lateral view, (D) terminalia, lateral view, and $(\mathrm{E})$ terminalia, ventral view; scale bar $=1 \mathrm{~mm}$.

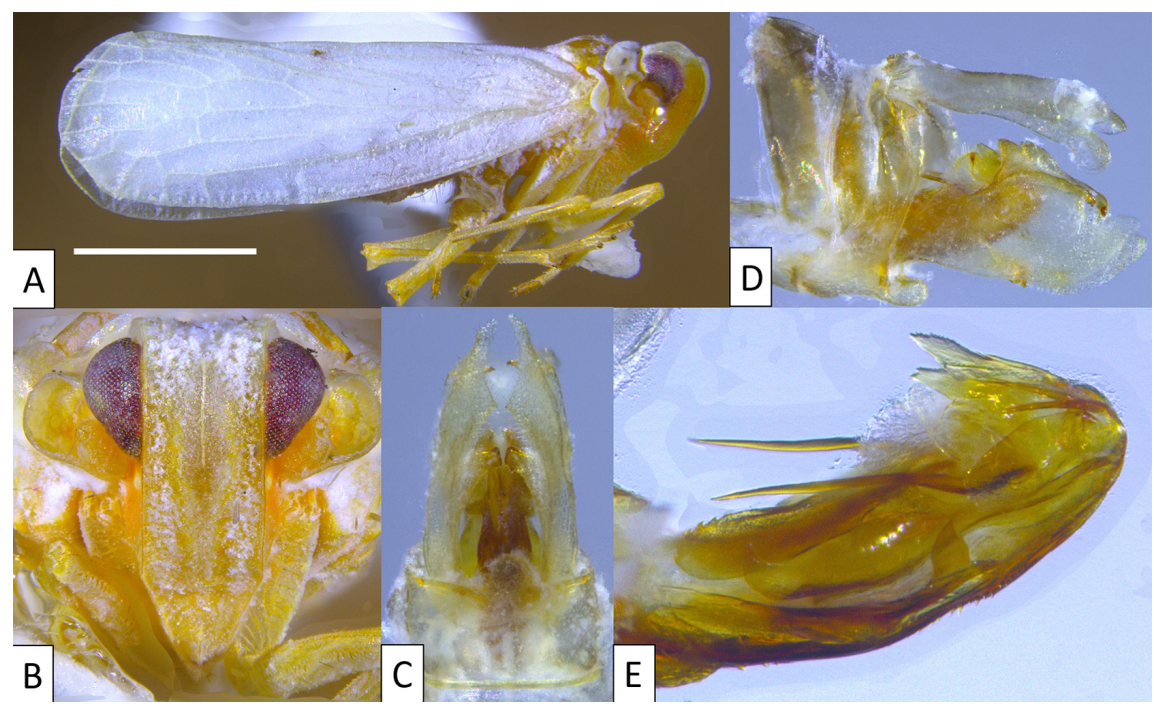

FIGURE 2. Herpis albida; (A) adult, male lateral view, (B) head, frontal view, (C) terminalia, ventral view, (D) terminalia, lateral view, and (E) aedeagus, lateral view; scale bar $=1 \mathrm{~mm}$.

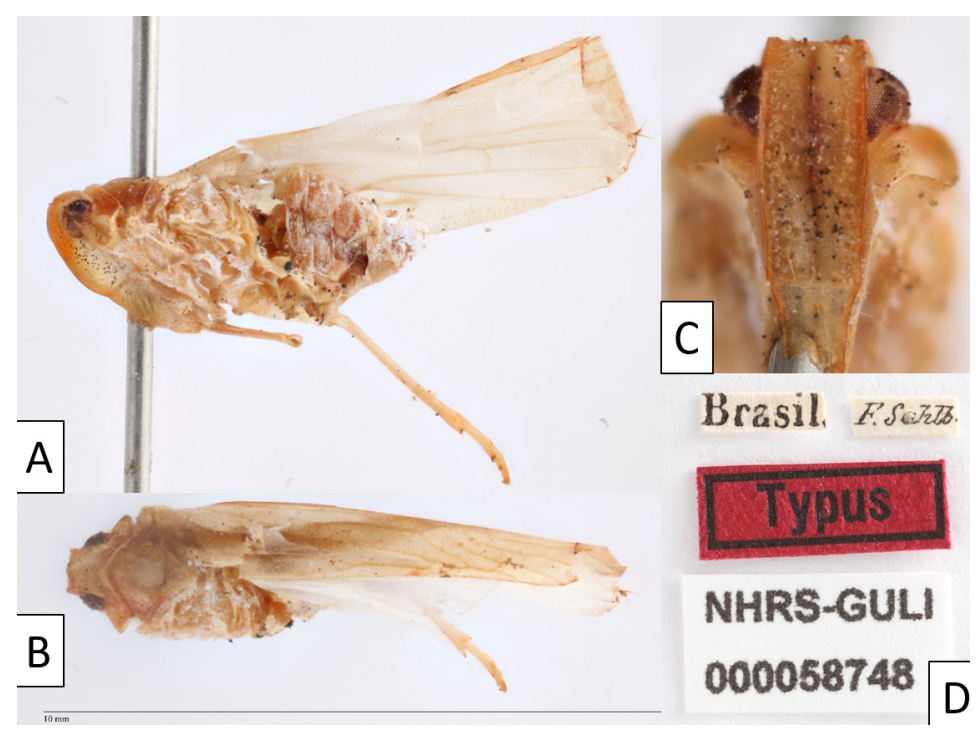

FIGURE 3. Herpis fuscovittata, holotype; (A) lateral view, (B) dorsal view, (C) head frontal view, and (D) labels. 


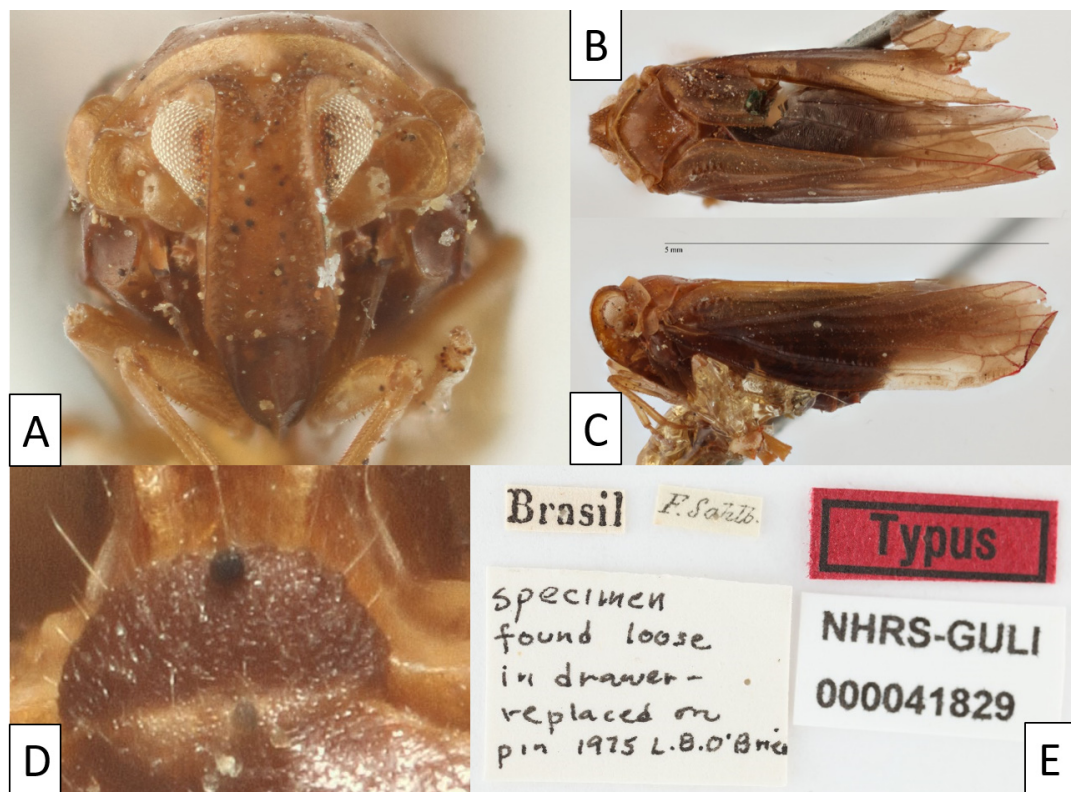

FIGURE 4. Holotype of Oropuna orba (Stål) comb. n.; (A) head, frontal view, (B) body, dorsal view, (C) body, lateral view, (D) female pregenital plate, and (E) labels.

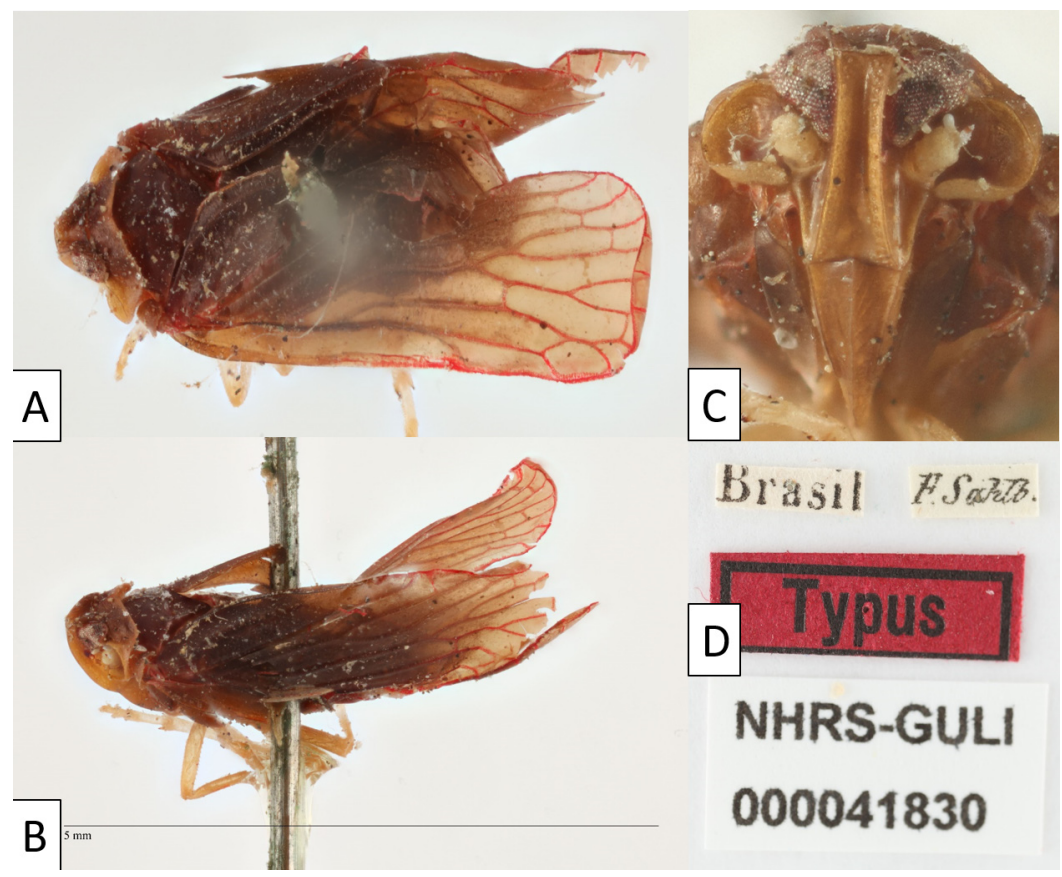

FIGURE 5. Holotype of Herpis fimbriolata (current combination Phaciocephalus fimbriolatus, incertae sedis); (A) body, dorsal view, (B) body, lateral view, (C) head frontal view, and (D) labels. 


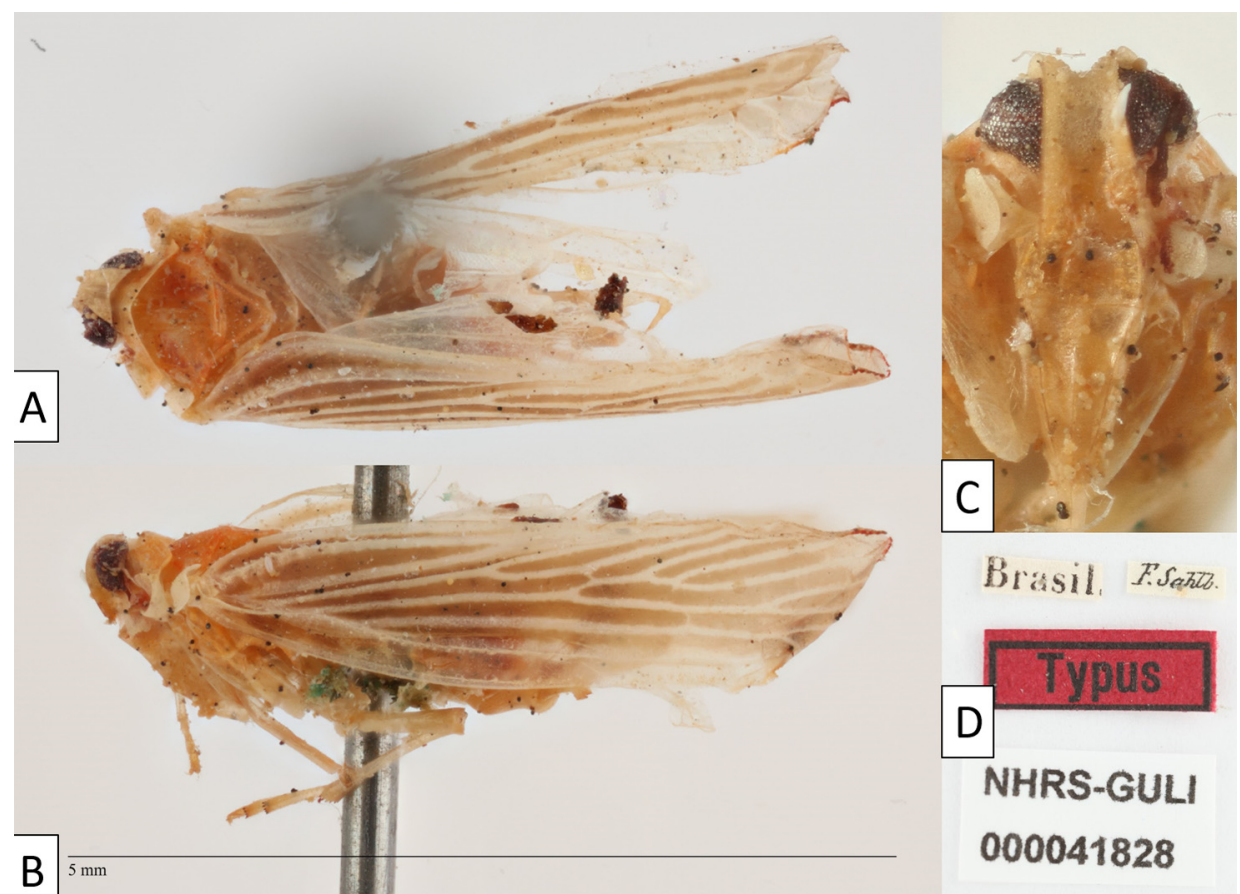

FIGURE 6. Holotype of Persis pallidovenosa (Stål) comb. n.; (A) body dorsal view, (B) body lateral view, (C) head frontal view, and (D) labels.

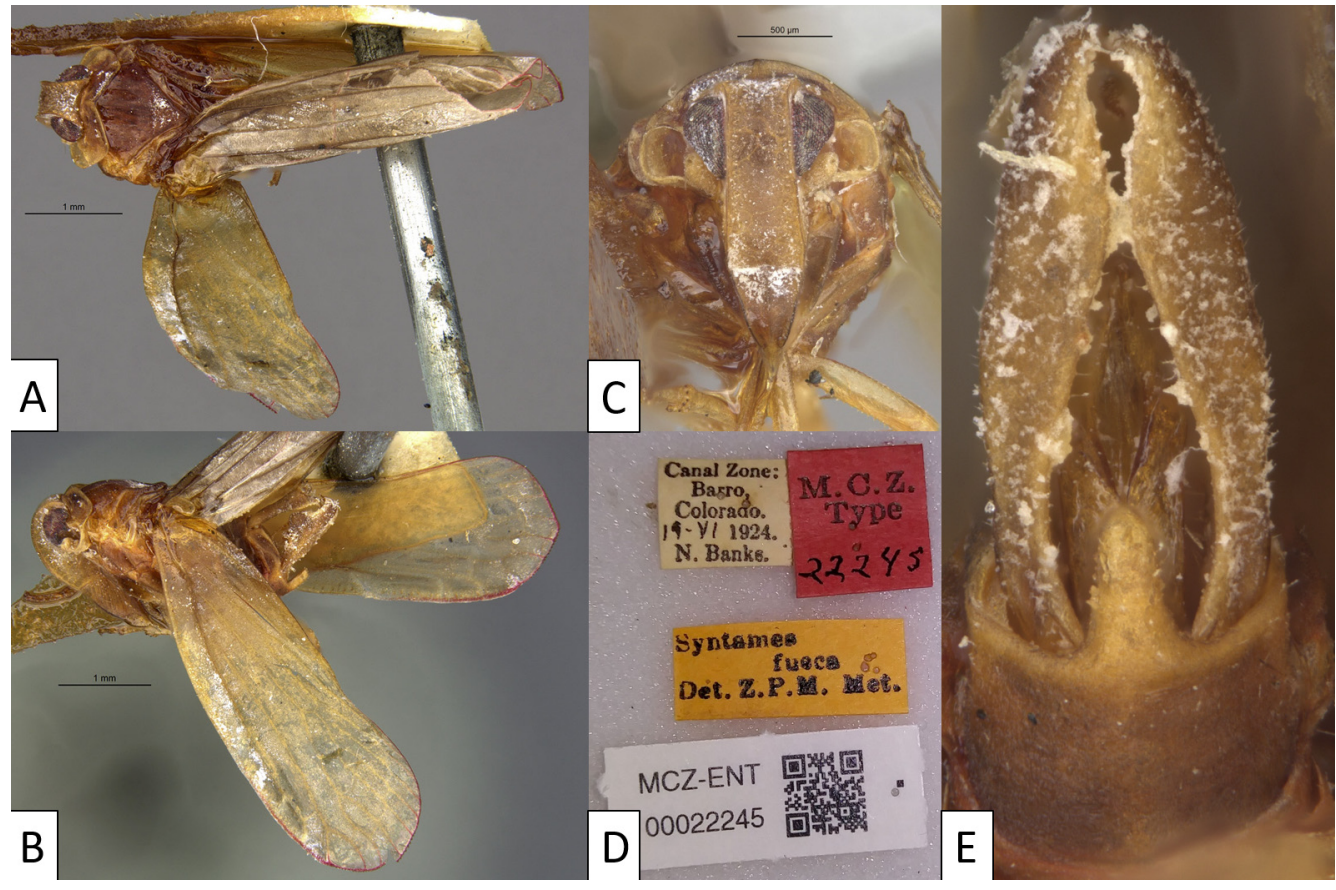

FIGURE 7. Holotype of Oropuna fuscus comb. n; (A) body dorsal view, (B) body lateral view, (C) head frontal view, (D) labels, and (E) terminalia ventral view. (image credit Museum of Comparative Zoology, Harvard University, CPresident and Fellows of Harvard College, used by permission).

\section{Systematics}

Family Derbidae Spinola 1839

Subfamily Derbinae Spinola 1839 


\section{Tribe Cenchreini Muir 1913}

\section{Genus Herpis Stål 1862}

Herpis Stål 1862: 8. Type species Herpis fuscovittata Stål, 1862, by subsequent designation of Muir 1924: 16 (see also McAtee 1924: 175).

Syntames Fowler, 1905 (Type species Syntames delicatus Fowler 1905, by monotypy). Synonym with Herpis according to Muir 1924: 16; Caldwell 1944: 99; O’Brien 1987: 383; treated as valid by Metcalf 1938: 324; 1945a: 101; 1945b: 125. Synonymy of Syntames with Herpis confirmed here.

Amended Diagnosis. Members of this genus are relatively large and robust among the Cenchreini, measuring approximately 4-8 $\mathrm{mm}$ in length, including wings. Wings held tectiform in repose, distinctly exceeding abdomen. Vertex broad, trapezoidal, just broader than long, nearly flat to weakly concave, transverse carinae present at fastigium. Pits present along lateral carinae of vertex and frons, varying in distinctness, appearing to be in $2+$ rows. Frons broad, flat (not concave), lateral margins parallel, medium carina of frons evident, frontoclypeal margin straight. Clypeus elongate triangular, approximately in the same plane as frons, median carina present. Genae without subantennal processes. Antennae short, pedicle spheroid, about as long as wide.

Pronotum narrow, posteriorly concave, broadening laterally, in lateral view declinate anteriorly; paranotal region foliate, forming large foveae posterior to the antennae (a tribal feature). Mesonotum tricarinate, carinae approximately reaching posterior margin, scutellum contiguous with scutum (i.e., not separated by groove). Lateral teeth absent on tibiae.

Terminalia bilaterally symmetrical. Pygofer in lateral view narrow, irregular in outline; in ventral view, median process of pygofer present (longer than wide, apically conical). Gonostyli elongate, broad, bearing dorsal projection in distal half, and in ventral view, usually with a medial process near midlength. Aedeagal shaft with processes apically and near midlength; flagellum complex, with elongate retrorse processes. Anal tube elongate in lateral view (but usually shorter than gonostyli), distally expanded; in dorsal view appearing spatulate with caudal margin strongly bifid.

Remarks. The species examined thus far that clearly belong in Herpis are all pallid in coloration, although survey efforts of the included taxa are incomplete. Indomalayan species currently placed in Herpis have not been examined. It is unlikely, from a biogeographic perspective, that these taxa are correctly placed (also noted by Metcalf 1938: 325), but review of these taxa was outside of the current scope, which is to consider New World taxa allied with those associated with palms. Images of the type specimen of Syntames delicatus Fowler from the British Museum confirm the synonymy of Syntames with Herpis. The images show the specimen with the venter glued to a card. Syntames delicatus is a pallid species, with a broad, flat roughly trapezoidal vertex, frons parallel sided, bearing a median carina, thorax with dark markings on the lateral portions of the thoracic nota, and dark markings in the forewings whose arrangement are not clear in the images, but consistent with O'Brien (1987, fig. 13).

The dark specimen reported and illustrated as Herpis sp. from palms in Dollet et al. (2020, fig. 3) is suspected to belong to Oropuna, but evaluation of all the needed features is not possible from the views provided.

Images of the type specimen of Syntames fuscus Metcalf, 1938 (Fig. 7, from the website of the Museum of Comparative Zoology (MCZC, Harvard University, Cambridge MA; CPresident and Fellows of Harvard College, used by permission), show that this species lacks a median carina on the frons; and the frons and vertex are somewhat concave, features that currently associated with Oropuna. For that reason, it is transferred to Oropuna as Oropuna fusca (Metcalf), new combination.

Photographs provided by the Swedish Museum of Natural History (NHRS, Stockholm) of three species originally described by Stål, 1862 in Herpis, (H. fimbriolata, H. orba, and H. pallidovenosa) but subsequently moved to Phaciocephalus by Muir 1924: 16 were also examined (as briefly noted in Dollet et al. 2020). The species described by Stål (1862) in Herpis are from Brazil, presumably the region around Rio de Janeiro, based on the title of the paper (roughly translated from Swedish as "Contribution to the Rio Janeiro area, Hemiptera fauna"). None of these species belong in Herpis or to Phaciocephalus. Phaciocephalus is a genus of the Oceania and Indomalayan Ecoregions, characterized in part by a broadly quadrate ventral process of the pygofer, a feature associated with Oropuna among New World Cenchreini. Photographs of the type specimen of Phaciocephalus vitiensis Kirkaldy, 1906, the type species of Phaciocephalus, from the Bernice P. Bishop Museum (BPBM, Honolulu, HI) were also examined to better understand features attributed to the genus. 
Phaciocephalus orbus (Fig. 4) is a dark species with a broad vertex and frons, lacking a median carinae, excluding it from Herpis. The habitus of the species, plus the broad vertex and frons, lacking a median carina, suggests the genus Oropuna, thus this species is transferred to Oropuna as Oropuna orba (Stål), new combination.

Phaciocephalus fimbriolatus (Fig. 5) has a deeply convex frons, lacking a median carina, excluding it from Herpis. The shape of the head is most suggestive of Tico Bahder \& Bartlett (in Bahder et al. 2021), but we consider this species as incertae sedis until additional specimens collected from palms that may belong to Tico are investigated.

Phaciocephalus pallidovenosus (Fig. 6) is a stramineous species with very conspicuous pale wing veins. The head is moderately broad, and the vertex and face are distinctly concave. The features of this species are suggestive of the genus Persis. The head of this species is not particularly projecting, which would place the species in either subgenus Anapersis Fennah or Eritalaena Fennah. Phaciocephalus pallidovenosus in habitus appears consistent with the subgenus Anapersis, including a long subcostal cell and pustules along the lateral carina of the vertex, features attributed to the subgenus. Therefore this species is transferred to Persis (Anapersis) as Persis (Anapersis) pallidovenosa (Stål), new combination.

Etymology. The original publication (Stål 1862) did not specify the derivation of the genus name, but "Herpis" is an Egyptian word for wine that was adapted into Greek, and is masculine in gender.

\section{Material examined.}

Herpis albida (Fig. 2) (male/non-type): Costa Rica, Heredia / nr Puerto Viejo, LaSelvaBio / Sta. $179 \mathrm{ft}, 10^{\circ} 25^{\prime}$ $84^{\circ} 00 \mathrm{~W} /$ at station, (23-II)-(2-III)-04 / CRBartlett, JCryan, JUrban. - New county record.

Herpis metcalfi (Fig. 1) (male/non-type) : PANAMA, Colon, C.Z. / Ft. Sherman, Old Ft. San / Lorenzo Rd.. 7-16-1995 / C.W.\&L.B.O'Brien // Herpis / metcalfi / O’Brien / det.L.O'Brien

Syntames fuscus Metcalf (holotype, photographs, Fig. 7): "Canal Zone: / Barro, / Colorado. / 19-VI 1924. / N. Banks. // M.C.Z. / Type / 2245 [red label] // Syntames / fusca / Det. Z.P.M. Met. [yellow label] // MCZ-ENT / 00022245 [2D barcode]" (MCZC, male).

Herpis fibriolata Stål (type, photographs, Fig. 5): "Brazil // F. Stalb. [R. F. Sahlberg] // Typus [red paper] // NHRS-GULI / 000041830 (NHRS, female).

Herpis fuscovittata Stål (type, photographs, Fig. 3): Brazil // F. Stalb. [R. F. Sahlberg] // Typus [red label] // NHRS-GULI / 000058748 (NHRS, female).

Herpis pallidovenosa Stål (type, photographs, Fig. 6): "Brazil // F. Stalb. [R. F. Sahlberg] // Typus [red label] // NHRS-GULI / 000041826 (NHRS, female).

Herpis orba Stål (type, photographs, Fig. 4): "Brazil // F. Stalb. [R. F. Sahlberg] // Typus [red paper] // Specimen / found loose / in drawer - / replaced on / pin 1975 L. B. O’Brien // NHRS-GULI / 000041829 (NHRS, female) [reported as male by Stål 1862].

Phaciocephalus vitiensis Kirkaldy (holotype): "Fiji Is. / 3 - 1905 // Coll. Koebele // ठ // 281 / Phacio = / cephalus / vitiensis / [?] type 281 Kirk [handwritten] / Holotype [red label, glued transversely // 733" (BPBM, male).

\section{Herpis soros $\mathbf{s p .} \mathbf{n}$.}

(Figures 8-12)

Type locality. Costa Rica, Heredia, La Selva Biological Station.

Diagnosis. Body pallid, wings marked with oblique fascia. Gonostyli in lateral view abruptly broadened near base, paddle-shaped, with angular process on oblique margin; in ventral view with large median hook just before midlength. Pygofer and aedeagus bilaterally symmetrical, each side with pair of elongate processed before midlength of shaft, the proximal ones (Fig 12, A1, A2) falcate (apex directed cephalad), distal processes (A3, A4) straight (apex directed dorsocaudad), and a pair (A5, A6) of short caudally directed processes in addition to apical retrorse processes and the endosoma. Anal tube in lateral view elongate, distally enlarged with ventral margin sinuate; in dorsal view abruptly expanded just before anal column into pair of stout processes. 


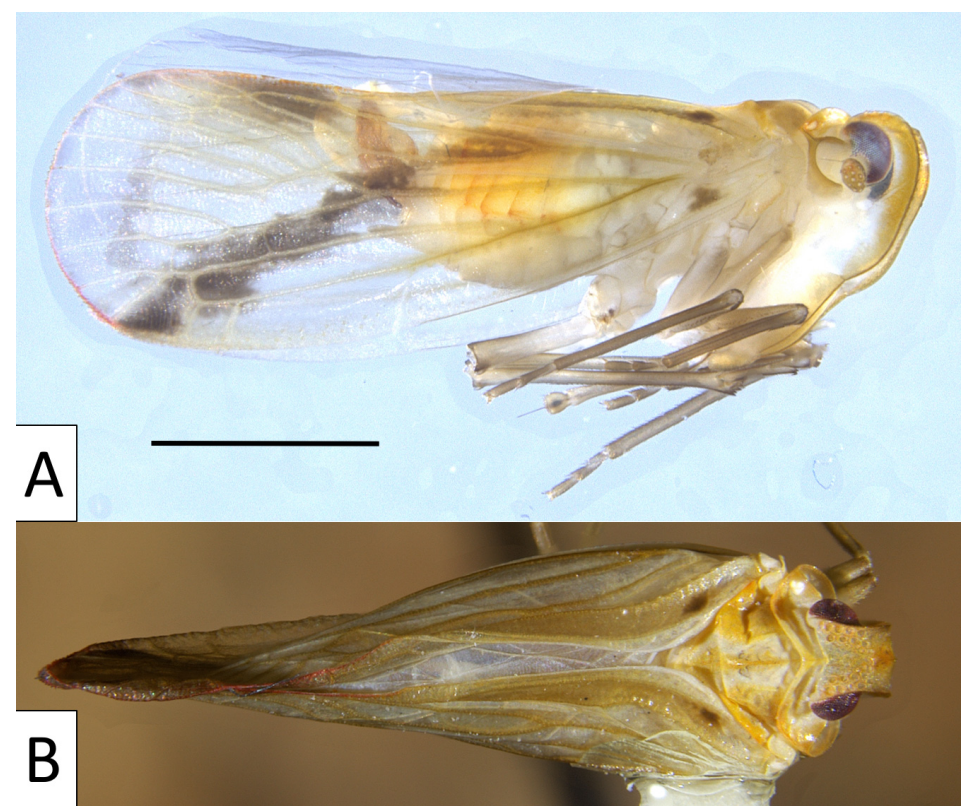

FIGURE 8. Adult habitus Herpis soros sp. n.; (A) male lateral view and (B) male dorsal view.

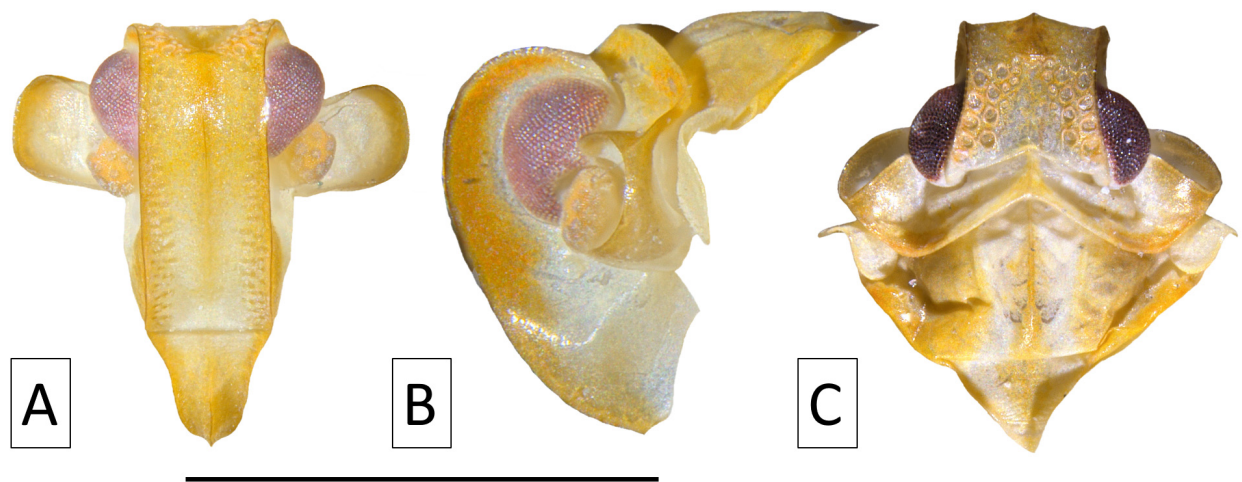

FIGURE 9. Adult Herpis soros sp. n.; (A) head and pronotum frontal view, (B) head, pronotum, and mesonotum lateral view, and $(\mathrm{C})$ head, pronotum, and mesonotum dorsal view; scale $=1 \mathrm{~mm}$.

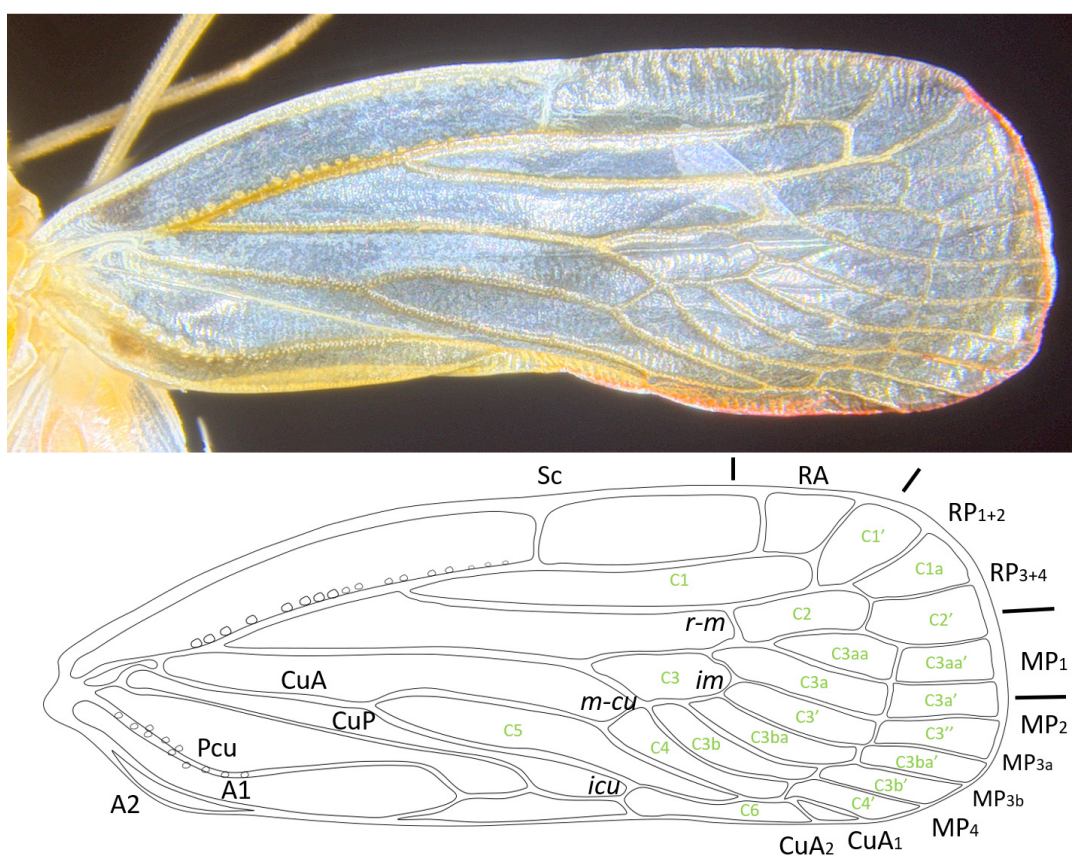

FIGURE 10. Male Herpis soros $\mathbf{s p .} \mathbf{n}$. forewing venation; black = vein, green $=$ cell, italics $=$ crossvein 


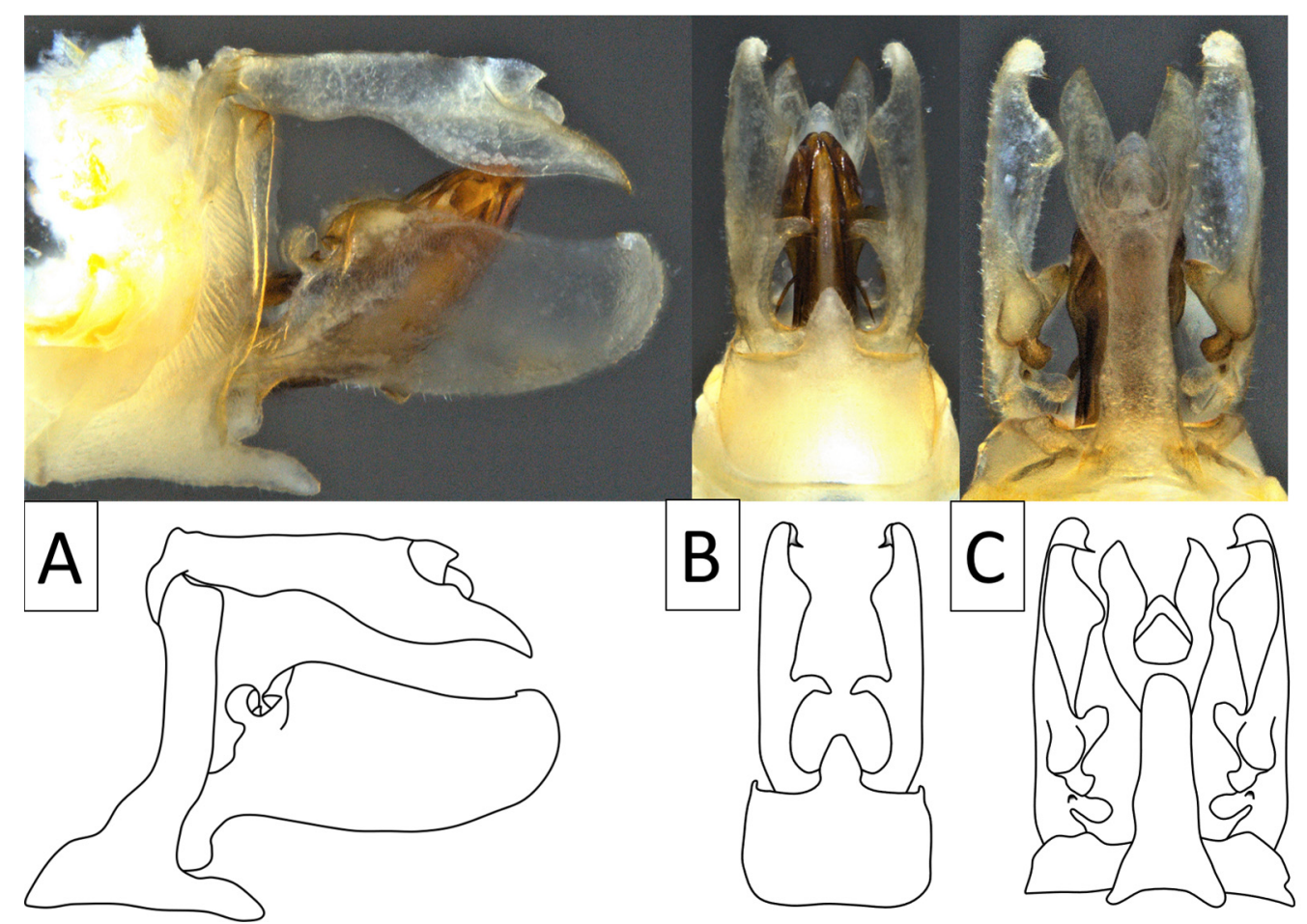

FIGURE 11. Male Herpis soros sp. n. terminalia; (A) lateral view, (B) ventral view, and (C) dorsal view.
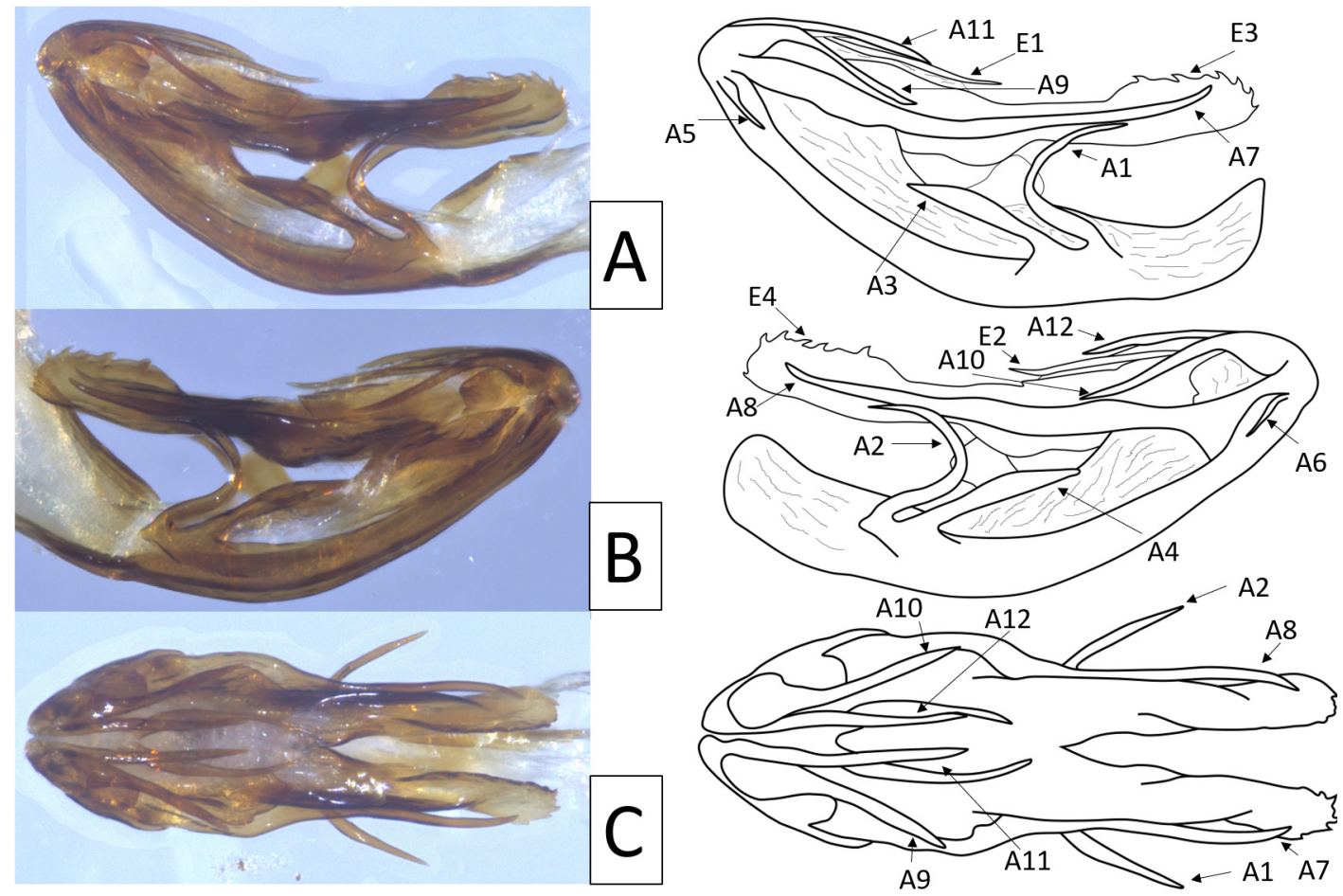

FIGURE 12. Aedeagus of adult male Herpis soros sp. n. (A) right lateral view, (B) left lateral view, and (C) dorsal view.

Description. Color. General body color predominantly white with yellowish (to tan) markings, abdominal tergites yellow-orange, anterior region of the head dull orange, pronotum dull orange, mesonotum with dull orange distad of lateral carinae, white mesad of lateral carinae (forming median vitta), median carina dull orange (Fig. 8). Forewing with fuscous oblique fascia extending from apex of RA proximad to fork of $\mathrm{CuA}$; fuscous patch in proximal portion of costal cell and trailing portion of clavus. Red along apical margin of forewing to tip of clavus, veins pale yellow distally, darker basally.

Structure. Body length male 3.99-4.01 ( $\mathrm{n}=3$, Table 2), female $4.11(\mathrm{n}=2)$. Head. Vertex broad, wider than long, 
widest basally, narrowed distally, posterior margin angulate, fastigium with anteriorly arched, transverse carina (most evident from frontal view; median carina obsolete on vertex, evident distad of transverse carina, creating a small protrusion); lateral carina with $2+$ rows of distinct pits, mixed in size, continuing to lateral margins of frons, diminishing in size and more irregularly arranged compared to vertex (Fig. 9C). In frontal view, vertex weakly concave (medially depressed); frons broad, lateral margins parallel, keeled and median carina distinct from transverse carina at fastigium to frontoclypeal suture (Fig. 9A). Frontoclypeal suture straight, clypeus elongately triangular with distinct median keel. In lateral view, head evenly rounded across fastigium (Fig. 9B). Antennae short (greatly overtopped by foliate paradiscal region of pronotum in frontal view, Fig. 9A), scape very small, pedicle spheroid, about as wide as tall. Rostrum exceeding hind coxae, terminal segment about as long as wide.

TABLE 2. Biometric data for Herpis soros sp. n. (in mm)

\begin{tabular}{lllll}
\hline & \multicolumn{3}{l}{ Male $(n=3)$} & Female $(n=2)$ \\
\cline { 2 - 5 } Character & Average \pm SE & Range & Average \pm SE & Range \\
\hline Body length with wings & $4.00 \pm 0.01$ & $3.99-4.01$ & $4.11 \pm 0.00$ & 4.11 \\
Body length without wings & $2.89 \pm 0.02$ & $2.88-2.91$ & $2.93 \pm 0.00$ & 2.93 \\
Forewing length & $3.34 \pm 0.01$ & $3.33-3.35$ & $3.36 \pm 0.00$ & 3.36 \\
Vertex length & $0.21 \pm 0.01$ & $0.21-0.22$ & $0.23 \pm 0.00$ & 0.23 \\
Vertex width - basal & $0.41 \pm 0.00$ & 0.41 & $0.42 \pm 0.00$ & 0.42 \\
Vertex width - distal & $0.31 \pm 0.00$ & 0.31 & $0.32 \pm 0.00$ & 0.32 \\
Pronotum length - midline & $0.10 \pm 0.00$ & 0.10 & $0.12 \pm 0.00$ & 0.12 \\
Mesonotum length - midline & $0.66 \pm 0.00$ & 0.66 & $0.68 \pm 0.00$ & 0.68 \\
Mesonotum width & $0.83 \pm 0.00$ & 0.83 & $0.85 \pm 0.00$ & 0.85 \\
Frons length & $0.74 \pm 0.10$ & $0.74-0.75$ & $0.76 \pm 0.00$ & 0.76 \\
Frons width - dorsal & $0.31 \pm 0.00$ & 0.31 & $0.33 \pm 0.00$ & 0.33 \\
Frons width - frontoclypeal & $0.31 \pm 0.00$ & 0.31 & $0.33 \pm 0.00$ & 0.33 \\
Clypeus length & $0.27 \pm 0.00$ & 0.27 & $0.28 \pm 0.00$ & 0.28 \\
\hline
\end{tabular}

Thorax. Pronotum narrow in dorsal view, anterior margin moderately convex, posterior margin deeply concave, median carina distinct with lateral disc depressed; in lateral view with posterior margin foliately raised (anteriorly declinate); paranotal region expanded and foliate, forming fossae surrounding antennae caudad in lateral view (Fig. 9B), from frontal view subquadrate, greatly exceeding antennae (Fig. 9A). Mesonotum at midline longer than vertex and pronotum combined; tricarinate, lateral carinae subparallel, obscure; median carina distinct on scutum, weaker on scutellum; notum mildly inflected between scutum and scutellum. Tibiae lacking lateral spines; spinulation of hind leg 6-6-7. Forewing (Fig. 10) with apex of clavus near wing midlength, fork of CuA just basad of Sc+RA and RP fork, both in proximal half of wing; wing branching pattern RA 2-branched, RP 2-branched, MP 6-branched, $\mathrm{CuA} 2$-branched (but see below); MP region of wing with 6 closed cells (C4-C3aa inclusive), wing cell C5 closed before wing margin, $\mathrm{Pcu}+\mathrm{A} 1$ joining $\mathrm{CuP}$ prior to the composite vein reaching wing margin (i.e., clavus open).

Terminalia. Pygofer in lateral view narrowest dorsally, widest ventrally, appearing trap-like with irregularly sinuate anterior and posterior margins (Fig. 11A); in ventral view, medioventral process of pygofer subtriangular at apex, lateral margins angled (Fig. 11B). Gonostyli in lateral view paddle-shaped, narrowest near base, becoming abruptly wider with complex angular processes on incline of dorsal margin, distal margin broadly rounded (Fig. 11A), with dorsal apical margin medially curved (to sharply acuminate apex, visible from dorsal and ventral views, Figs. 11B, 11C); dorsal angular processes highly complex from dorsal view (Fig. 11C), rounded lobe with sclerotized tooth arising from base, second, larger lobe with constriction, forming circular apex angled mesad. In ventral view, gonostyli wide at base, abruptly constricting to sinuate medioventral margin bearing large, medial falcate processes before midlength (Fig. 11B). Aedeagus bilaterally symmetrical, in lateral view shaft upcurved bearing complex series of processes, including elongate processes along shaft and at apex plus complex endosoma (Fig. 12); shaft with pair of elongate processes (A1-A4) arising from lateral margin before midlength on common base, A1 and $\mathrm{A} 2$ slender and strongly falciform, apices directed anteriorly (from dorsal view, A1 and A2 laterally projecting, Fig. 12C), A3 and A4 more robust, straight, directed posteriorly (Figs. 12A \& 12B); shaft with two pair of subapical processes (A5-A8), first pair (A5 \& A6) short and caudally directed processes, and second pair (A7 \& A8) retrorse 
and very elongate, extending almost to base of aedeagus; two pair of apical retrorse processes (A9-A12), both pair of moderate length, approximately 1/3 length of A7 \& A8; processes A9 \& A10 slightly downcurved; endosoma complex with one pair of dorsal processes (E1 \& E2), and one pair of stout, elongate serrate lobes (E3 \& E4); processes E1 \& E2 arising at dorsal midline, curved medially, slender, extending to about midpoint of aedeagus; lobes E3 \& E4 broad, extending to aedeagal base, serrate at apex and along dorsal margin, serrations terminating near level of A1 and $\mathrm{A} 2$ apices.

Plant associations. Palm (Arecaceae) seedlings along trail of primary growth forest.

Distribution. Costa Rica (Heredía Province).

Etymology. The specific epithet "soros" is a Greek term meaning heap or pile, referring to the collection of processes on top of the aedeagus, and is masculine in gender.

Material examined. Holotype male, "Costa Rica, Heredía Pr. / La Selva Biological Station / 21-VI-2019 / Coll.: B.W. Bahder / sweeping palm seedlings // Holotype / Herpis soros" (FLREC). Paratypes, same as holotype (3 males, 2 females, FLREC and FSCA).

Sequence Data. The phylogenetic analysis based on COI and 18S data shows moderate support (85) for Herpis soros sp. n. representing a separate clade relative to other taxa with molecular data available (Fig. 13). Compared to other genera within the Cenchreini, Herpis soros sp. n. differed by an average of $18.4 \%( \pm 0.45)$ for the COI locus and $7.4 \%( \pm 0.45)$ for the $18 \mathrm{~S}$ locus. For COI, the average variability within species was $16.3 \%( \pm 0.55), 16.0 \%$ ( \pm 0.44 ), and $14.4 \%$ for Agoo, Omolicna, and Tico, respectively while the variability among genera was $19.2 \%$ $( \pm 0.75)$. For $18 \mathrm{~S}$, the average variability within species was $1.04 \%( \pm 0.1), 1.15 \%( \pm 0.06)$, and $0.88 \%$ for Agoo, Omolicna, and Tico, respectively while the variability among genera was $7.44 \%( \pm 0.84)$.

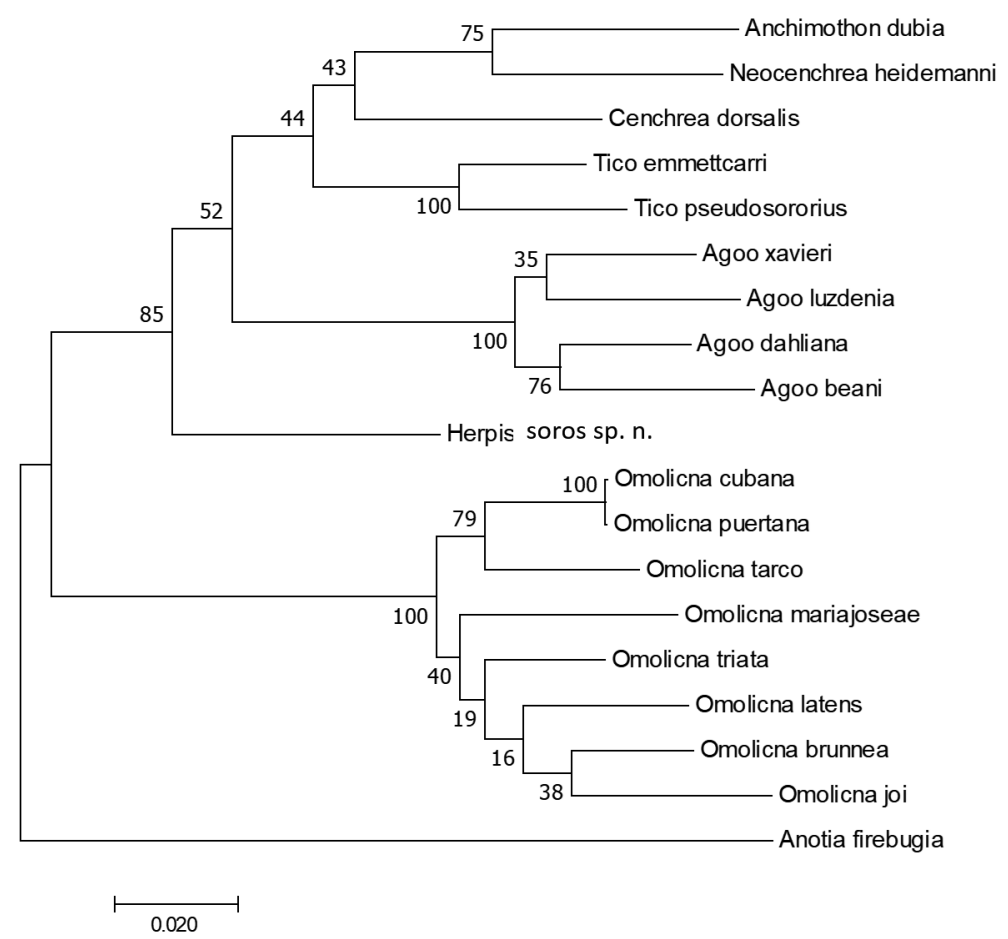

FIGURE 13. Maximum Likelihood consensus tree (1,000 replicates) based on COI and 18S sequence data for currently available Cenchreini planthoppers with Anotia firebugia (Otiocerini) as outgroup.

Remarks. The new species placement in Herpis is strongly supported based on morphological characters. External diagnostic features for the genus include relatively large and stout (among New World Cenchreini), frons broad and parallel sided, bearing a median carinae, frontoclypeal margin straight; vertex broad (nearly flat from frontal view). Among species so far examined ascribed to Herpis (H. metcalfi, Fig. 1, H. albida, Fig. 2, and $H$. fuscovittata, Fig. 3), they are all relatively pale in coloration. Genus-level features for the terminalia include broad, elongate parameres, each bearing a dorsal process and, in ventral view, a median hook; the aedeagus with a complex array of processes on the shaft and associated with the endosoma; and the anal tube elongate and, in dorsal view, apically bifid. These features appear to be consistent among the new species and terminalia figured by O'Brien 1987 (fig. 23 H. delicata, and fig. 17, H. metcalfi). 
Herpis soros sp. n. appears to be most similar to Herpis metcalfi (Fig. 1), including the terminalia (O'Brien 1987, fig. 17). The gonostyli and aedeagus both appear similar, however, the A1 \& A2 processes are not falciform in $H$. metcalfi, and they differ in the shape of the gonostyli (H. metcalfi are apically narrowed instead of broadly rounded).

The phylogenetic analysis (Fig. 13) based on COI and 18S supports the novel taxon being distinct from other members of the Cenchreini, but the relationship of Herpis soros sp. n. to other congeners and variability within Herpis is unknown due to lack of sequence data from currently described taxa.

\section{Discussion}

The discovery of a novel species of planthopper in the genus Herpis and the generation of sequence data for a previously understudied group from a phylogenetic perspective significantly enhances our understanding of the diversity of the Cenchreini and the overall evolutionary relationships among the New World cenchreine genera. Currently, no other genus within this tribe is as easily distinguished based on external morphological characteristics. However, additional fresh collections on Herpis are needed to test generic monophyly and further explore evolutionary hypotheses, especially since obtaining sequence data from old collections is unreliable. While obtaining sequence data from older museum specimens of this group will likely not be possible, based on the loci analyzed, obtaining novel sequence data for new species within Herpis will be critical for establishing the monophyly of the genus.

The forewing venation of Herpis soros sp. n., like many other derbids, might be interpreted in different, equally parsimonious ways. We are attempting to interpret the venation following Bourgoin et al. (2015), which is in turn based partly on Emeljanov (1996), who outlines some general ideas and alternative interpretations for derbids (viz. that of Muir 1918, Synave 1973, Broomfield 1985, Dworakowska 1988). According to Emeljanov (1996: 74), the CuA has a 'double apex' (i.e., is forked), with a "permanent transverse vein near the apex of the clavus connecting $\mathrm{CuA}_{2}$ with the marginal vein of the membrane" (i.e., an icu crossvein from $\mathrm{CuA}_{2}$ to the wing margin near the claval apex). Emeljanov (1996) notes that while the forked CuA usually forms an open cell (an open C5 cell, according to the nomenclature of Bourgoin et al. 2015), it is sometimes closed (to form the 'procubital cell'). In Herpis, it appears that the icu connects to the combined $\mathrm{CuP}+\mathrm{Pcu}+\mathrm{A} 1$, prior to the composite vein reaching the wing margin. The $\mathrm{CuA}_{2}$ joins once again with the $\mathrm{CuA}_{1}$ forming a closed C5 (procubital cell), and an open, marginal C6. However, it might also be possible to interpret the icu as the $\mathrm{CuA}_{2}$, with an elongate crossvein between $\mathrm{CuA}_{1}$ and $\mathrm{CuA}_{2}$ forming an open C5' cell instead (which is tempting given the aligned sequence of crossveins across the MP region). Also, the positioning of the im crossvein could be questioned, leading to a sequence of changes in cell and vein nomenclature. A comparative study of derbid tegmina to establish patterns and rules of vein (and cell) interpretation would be helpful to stabilize nomenclature, especially where venation variation is asserted as a useful evolutionary character in a phylogenetic context. In the meantime, explicit annotation of key forewing venation features would limit the confusion among the multiplicity of possible venation interpretations, especially where these features are used for diagnostics (i.e., the keys to cenchreine genera by Fennah (1952) and O’Brien (1982).

\section{Acknowledgements}

We are grateful for curators at Natural History collections for providing photos of critical specimens, including Jim Boone of The Bernice P. Bishop Museum (Honolulu, HI) for photos of Phaciocephalus vitiensis, and Gunvi Lindberg from the Swedish Museum of Natural History for photos of 4 type specimens from the Stål collection. We also thank Bob Blinn at North Carolina State, Department of Entomology (Raleigh, NC) and The Museum of Comparative Zoology-Harvard Museum for making photographs of type specimens available online (MCZ images Museum of Comparative Zoology, Harvard University, CPresident and Fellows of Harvard College, used by permission), which were helpful for our studies, and to Mick Webb, Hemiptera curator at the British Museum (Natural History), for images of the type of Syntames delicatus and helpful correspondence. We are grateful to Luz Bahder for translating the abstract into Spanish. 


\section{References}

Bahder, B.W., Bartlett, C.R., Barrantes, E.A.B., Echavarria, M.A.Z., Humphries, A.R., Helmick, E.E., Ascunce, M.S. \& Goss, E.M. (2019) A new species of Omolicna (Hemiptera: Auchenorrhyncha: Fulgoroidea: Derbidae) from coconut palm in Costa Rica and new country records for Omolicna brunnea and Omolicna triata. Zootaxa, 4577 (3), 501-514. https://doi.org/10.11646/zootaxa.4577.3.5

Bahder, B.W., Zumbado Echavarria, M.A., Barrantes E.A.B., Helmick, E.E. \& Bartlett, C.R. (2021) A new genus and two new species of planthopper in the tribe Cenchreini (Hemiptera: Auchenorrhyncha: Derbidae) from lowland tropical rainforest in Costa Rica, Zootaxa, 4908 (3), 369-392. https://doi.org/10.11646/zootaxa.4908.3.3

Bartlett, C.R., O’Brien, L.B. \& Wilson, S.W. (2014) A review of the planthoppers (Hemiptera: Fulgoroidea) of the United States. Memoirs of the American Entomological Society, 50, 1-287.

Bourgoin, T. (1988) A new interpretation of the homologies of the Hemiptera male genitalia illustrated by the Tettigometridae (Hemiptera, Fulgoromorpha). In: Vidano, C. \& Arzone, A. (Eds.), Proceedings of the $6^{\text {th }}$ Auchenorrhyncha Meeting, Turin, Italy, 7-11 September 1987. Consiglio Nazionale delle Ricerche, IPRA, Rome, pp. 113-120.

Bourgoin, T. (2021) FLOW (Fulgoromorpha Lists on The Web): a world knowledge base dedicated to Fulgoromorpha. Version 8. Updated 23 February 2021. Available from: http://hemiptera-databases.org/flow/ (accessed 23 February 2021)

Bourgoin, T. \& Huang, J. (1990) Morphologie comparée des genitalia mâles des Trypetimorphini et remarques phylogénétiques (Hemiptera: Fulgoromorpha: Tropiduchidae). Annales de la Société Entomologique de France, Nouvelle Serie, 26, $555-564$.

Bourgoin, T., Wang, R.R., Asche, M., Hoch, H., Soulier-Perkins, A., Stroinski, A., Yap, S. \& Szwedo, J. (2015) From micropterism to hyperpterism: recognition strategy and standardized homology-driven terminology of the forewing venation patterns in planthoppers (Hemiptera: Fulgoromorpha). Zoomorphology, 134 (1), 63-77. https://doi.org/10.1007/s00435-014-0243-6

Broomfield, P.S. (1985) Taxonomy of Neotropical Derbidae in the new tribe Mysidiini (Homoptera). Bulletin of the British Museum (Natural History), Entomology, 50 (1), 1-152.

Caldwell, J.S. (1944) The tribe Cenchreini with special references to the Cenchrea complex (Homoptera: Derbidae). Bulletin of the Brooklyn Entomological Society, 39, 99-110.

Dollet, M., Fidelis, E.G., Dos Passos, E., Da Silva, F., Aberlenc, H.P., Schurt, D.A., Bahder, B., Diniz, L.C. \& Bartlett, C.R. (2020) Derbid planthoppers (Hemiptera: Fulgoroidea: Derbidae) associated with coconut and oil palm in Brazil. Neotropical Entomology, 49, 722-738.

https://doi.org/10.1007/s13744-020-00788-5

Dworakowska, I. (1988) Main veins of the wings of Auchenorrhyncha (Insecta, Rhynchota: Hemelytrata). Entomologische Abhandlungen Staatliches Museum für Tierkunde Dresden, 52 (3), 63-108.

Emeljanov, A.F. (1996) On the system and phylogeny of the family Derbidae (Homoptera, Cicadina). Entomological Review, 75 (2), 70-100. [English translation of Entomologicheskoe Obozrenie, 73 (4), 783-811 (1994) from Russian]

Fabricius, J.C. (1803) Rhyngota. In: Systema rhyngotorum: secundum ordines, genera, species: adiectis synonymis, locis, observationibus, descriptionibus. C. Reichard. Brunsvigae, pp. 1-101.

Fennah, R.G. (1952) On the generic classification of Derbidae (Homoptera: Fulgoroidea) with descriptions of new Neotropical species. Transactions of the Royal Entomological Society of London, 103 (4), 109-170. https://doi.org/10.1111/j.1365-2311.1952.tb01063.x

Folmer, O., Black, M., Hoeh, W., Lutz, R. \& Vrijenhoek, R. (1994) DNA primers for amplification of mitochondrial cytochrome $C$ oxidase subunit I from diverse metazoan invertebrates. Molecular Marine Biology and Biotechnology, 3 (5), $294-299$.

Fowler, W.W. (1905) Order Rhynchota. Suborder Hemiptera-Homoptera. (Continued). Biologia Centrali-Americana, 1, 125139.

Kirkaldy, G.W. (1906) Leafhoppers and their natural enemies. (Pt. IX Leafhoppers. Hemiptera). Bulletin of the Hawaiian Sugar Planters' Association Experiment Station. Division of Entomology, 1 (9), 271-479.

Kumar, S., Stecher, G. \& Tamura, K. (2016) MEGA7: Molecular Evolutionary Genetics Analysis version 7.0 for bigger datasets. Molecular Biology and Evolution, 33, 1870-1874. https://doi.org/10.1093/molbev/msw054

McAtee, W.L. (1924) Notes on Cenchrea Westwood and Cedusa Fowler in America (Homoptera: Fulgoroidea). Annals of the Entomological Society of America, 17, 175-186. https://doi.org/10.1093/aesa/17.2.175

Metcalf, Z.P. (1938) The Fulgorina of Barro Colorado and other parts of Panama. Bulletin of the Museum of Comparative Zoology at Harvard College, 83 (5), 277-423.

Metcalf, Z.P. (1945a) General Catalogue of the Hemiptera. Fascicle IV. Fulgoroidea. Part 4. Derbidae. Smith College, Northhampton, Massachusetts, $212 \mathrm{pp}$.

Metcalf, Z.P. (1945b) Fulgoroidea (Homoptera) of Kartabo, Bartica District, British Guiana. Zoologica [Scientific contributions of the New York Zoological Society], 30 (3), 125-143.

Muir, F.A.G. (1913) On some new species of leafhoppers. Part II. Derbidae. Bulletin of the Hawaiian Sugar Planters'Association Experiment Station, Division of Entomology, 12, 28-92. 
Muir, F.A.G. (1917) The Derbidae of the Philippine Islands. Philippine Journal of Science, 12, 49-105.

Muir, F.A.G. (1918) Notes on the Derbidae in the British Museum collection.-I. Zoraidinae. Entomologist's Monthly Magazine, $54,173-177$.

Muir, F.A.G. (1924) Notes on some genera of Derbidae (Hemip.). Proceedings of the Entomological Society of Washington, 26, $15-19$.

O’Brien, L.B. (1982) Two Neotropical derbid genera with observations on wing rolling (Fulgoroidea: Homoptera). Florida Entomologist, 65 (3), 306-321.

O'Brien, L.B. (1987) Corrections and additions to Metcalf’s "The Fulgorina of Barro Colorado and other parts of Panama" (Homoptera: Fulgoroidea). Annals of the Entomological Society of America, 80 (3), 379-390. https://doi.org/10.1093/aesa/80.3.379

Simon, C., Frati, F., Beckenbach, A., Crespi, B., Liu, H. \& Flook, P. (1994) Evolution, weighting, and phylogenetic utility of mitochondrial gene sequences and a compilation of conserved polymerase chain reaction primers. Annals of the Entomological Society of America, 87 (6), 651-701. https://doi.org/10.1093/aesa/87.6.651

Spinola, M. (1839) Essai sur les Fulgorelles, sous-tribu des Cicadaires, ordre des Rhyngotes. Annales de la Société Entomologique de France, 8, 133-337.

Stål, C. (1862) Bidrag till Rio de Janeiro-tratkens Hemipterfauna. II. Handlingar. Kongliga Svenska Vetenskaps-Akademien, 3 (6), $1-75$.

Synave, H. (1973) Monographie des Derbidae Africains (Homoptera-Fulgoroidea). Etudes du Continent Africain [Etudes et Contributions Africaines], 2, 1-223.

Urban, J.M. \& Cryan, J.R. (2007) Evolution of the planthoppers (Insecta: Hemiptera: Fulgoroidea). Molecular Phylogenetics and Evolution, 42 (2), 556-572.

https://doi.org/10.1016/j.ympev.2006.08.009 